\title{
Metabolism of Testosterone and Androstenedione in Normal and Ovariectomized Women
}

\author{
G. E. Abraham, J. Lobotsky, and C. W. Lloyd \\ From the Worcester Foundation for Experimental Biology, \\ Shrewsbury, Massachusetts 01545
}

A B S T R A C T Metabolic clearance rates of testosterone $\left(M^{2} R^{T}\right)$ and androstenedione $\left(M^{A} R^{\mathbf{A}}\right)$ were determined twice during the same cycle in six normal women, using a constant infusion of testosterone- ${ }^{3} \mathrm{H}$ and androstenedione- $-{ }^{14} \mathrm{C}$. Nonlabeled steroids served as internal standards. Plasma concentrations of testosterone $\left(i^{T}\right)$ and androstenedione $\left(\mathrm{i}^{\mathbf{A}}\right)$ were measured, and the blood production of testosterone $\left(\mathrm{P}_{\mathbf{B}}{ }^{\mathrm{T}}\right)$ and of androstenedione $\left(\mathrm{P}_{\mathbf{B}}{ }^{\mathbf{A}}\right)$ were calculated. The interconversions of these two steroids were also estimated. Six ovariectomized women were studied in the same manner. For testosterone, the mean $\mathrm{i}^{\mathbf{T}}$ in the normal women was not significantly different from that in the ovariectomized subjects, whereas the $M^{2} R^{T}$ and $P_{B}{ }^{T}$ were significantly lower in the ovariectomized subjects. For androstenedione, the mean $\mathrm{MCR}^{\mathbf{\Delta}}$ values of the two groups of subjects were not different, whereas the $i^{\mathbf{A}}$ and $\mathrm{P}_{\mathbf{B}} \mathbf{A}^{\mathbf{\Delta}}$ in the normal women were about double those in the ovariectomized subjects. In comparing the follicular and luteal phases of the menstrual cycle in four of six subjects there was no difference in $i^{\mathbf{T}}, \mathrm{MCR}^{\mathbf{T}}$, or $\mathrm{P}_{\mathbf{B}} \mathbf{T}$, whereas $i^{\mathbf{A}}$, $\mathrm{MCR}^{\mathbf{A}}$, and $\mathrm{P}_{\mathbf{B}}{ }^{\mathbf{A}}$ were increased in the luteal phase. In one ovariectomized woman infused with testosterone and androstenedione at physiologic levels, $\mathrm{MCR}^{\mathrm{T}}$ doubled but $\mathrm{MCR}^{\mathrm{A}}$ remained the same. After six wk on estrogen, the same subject did not show any change in $\mathrm{MCR}^{\mathbf{T}}$ after infusion of testosterone. It is suggested that $\mathrm{MCR}^{\mathrm{T}} \mathrm{de}$ pends on $\mathrm{P}_{\mathbf{B}} \mathbf{T}$ and on plasma binding of testosterone which is partly estrogen dependent.

\section{INTRODUCTION}

Androgen metabolism in the human is so complex (1-3) that a comprehensive study involving the same sub-

This work was presented in part at the 3rd International Congress of Endocrinology in Mexico City on 5 July 1968.

Dr. Abraham is a Fellow, Steroid Training Program, supported by U. S. Public Health Service Grant No. 2T4 CA 5001-10 and Grant No. AM-08184, National Institutes of Health.

Received for publication 1 October 1968. jects would be most meaningful. As almost every physiologic measurement studied in the human female seems to be influenced by the ovarian cycle (4), an accurate timing of this cycle is obviously a prerequisite for a worthwhile evaluation and comparison of the data obtained. Two factors are of prime importance in deciding which parameters should be sudied: first, the availability and reliability of methods for measurement, and second, the clinical usefulness of the data obtained by these methods. In the field of androgens, attention is usually directed to the most potent androgen known, testosterone. Since androstenedione is readily interconvertible with testosterone $(1,5-7)$, the former should be included in investigations of androgen metabolism. Several methods have been described for the measurement of the production rate and interconversion of specific androgens. The advantages of the "blood" methods over the "urinary" methods have been emphasized by Tait and Burstein (2) and Horton and Tait (5). Those advantages hold true more so when the production rate of testosterone is measured in women, since most of the urinary testosterone glucuronide which is assumed to be the unique metabolite of testosterone in the "urinary" methods derives mainly from androstenedione by direct hepatic conversion to testosterone glucuronide without ever entering the circulation as free testosterone (8). Therefore, using the concept of metabolic clearance rate $(2,9)$ and the adaptation of this concept to the measurement of the blood production rate of testosterone and androstenedione (5), we have studied the dynamics of these two androgens during the menstrual cycle in normal women and also in ovariectomized subjects.

\section{METHODS}

Subjects. The subjects studied consisted of two groups (Table I). Group I included normally menstruating, adult women who claimed to be on no medication during the study period. Basal body temperatures were obtained daily. Urinary pregnanediol was determined on days 10 and 22 of the cycle. By use of these indirect indices of ovulation, five of the six subjects had an ovulatory cycle. (Subject No. 5 
had a flat temperature curve, and there was no increase in urinary pregnanediol.) An attempt was made to perform one infusion experiment during the follicular phase and another infusion during the luteal phase of the same cycle. It was successful in four of the subjects. The second infusion on subject No. 4 was performed on the day of thermal nadir $(T N=0)$. Thermal nadir was considered as the demarcation line between the follicular and the luteal phases of the cycle. Group II consisted of six ovariectomized women who were otherwise in good general health and on no medication for at least 6 wk before the study period.

Infusion experiments. Testosterone- $1,2-{ }^{3} \mathrm{H}$ (specific activity $42 \mathrm{c} / \mathrm{mmole}$ ) and androstenedione-4- ${ }^{14} \mathrm{C}$ (specific activity $50 \mathrm{mc} / \mathrm{mmole}$ ) were obtained from New England $\mathrm{Nu}$ clear Corp., Boston, Mass., and found to be over $95 \%$ pure by scanning of the chromatogram after chromatography on a Bush system (stationary phase, methanol: water 85:15; mobile phase, Skelly C). A mixture of the two radioactive steroids was prepared in a $22 \mathrm{ml}$ solution of $10 \%$ ethanol in normal saline just before the infusion. Approximately 10-20 $\mu \mathrm{c}$ of testosterone $-{ }^{3} \mathrm{H}$ and $2-4 \mu \mathrm{c}$ of androstenedione $-{ }^{14} \mathrm{C}$ were used. Sterilization of the infusion solution was achieved by passing it through a $0.5 \mu$ Millipore filter. There was no significant loss of either steroid on the filtration apparatus.

After the fasting subjects had been in the decubitus position from 8 to 9 a.m., $50 \mathrm{ml}$ of venous blood was drawn into heparinized syringes from the left cubital vein with a No. 18 Rochester needle which was left in place for further use. This sample was used to determine the plasma levels of testosterone and androstenedione. A solution of isotonic $\mathrm{NaCl}$ was administered intravenously through the right cubital vein with a No. 18 Rochester needle. At 9:30 a.m. a loading dose of the infusion mixture consisting of about one-third of the total amount of radioactivity administered ( $7 \mathrm{ml}$ volume from a total of $22 \mathrm{ml}$ ) was slowly injected through the rubber section of the IV tubing. At 10 a.m. the infusion was started through a Teflon tubing (10) with a
Harvard constant infusion pump at a rate of $0.0764 \mathrm{ml} / \mathrm{min}$. Samples collected for $5 \mathrm{~min}$ from the Teflon tubing pre- and postinfusion were used to calculate the delivery rate of the radioactive steroids. The infusion was continued for a period of $2 \mathrm{hr}$. These data are presented in Table II. In subject No. 8 the infusion was extended to $4 \mathrm{hr}$, using a larger volume of the two radioactive steroids, but at the same concentrations as in the other subjects. $50 \mathrm{ml}$ of venous blood was drawn into heparinized syringes at 90,105, and $120 \mathrm{~min}$ after the start of the infusion. These samples were used to study the metabolic clearance rate and conversion ratio of the two steroids. In subject No. 8, after the $120 \mathrm{~min}$ blood sample was drawn, a constant infusion of a $10 \%$ ethanol solution in normal saline of testosterone and androstenedione was started with another Harvard pump at a rate of $0.0764 \mathrm{ml} / \mathrm{min}$, corresponding to a delivery rate of 0.5 $\mu \mathrm{g} / \mathrm{min}$ for testosterone and $3.0 \mu \mathrm{g} / \mathrm{min}$ for androstenedione. This second infusion was continued for $2 \mathrm{hr}$ while the radioactive steroid infusion was still running. $25 \mathrm{ml}$ of venous blood was drawn in the same manner at $30,60,90,105$, and $120 \mathrm{~min}$ after the start of the second infusion. Those samples were used only to determine the metabolic clearance rate. The blood samples were centrifuged immediately after being drawn, and the plasma obtained was kept frozen until assayed.

Plasma steroids. Plasma testosterone and androstenedione were estimated by combining the double-isotope techniques using thiosemicarbazide- ${ }^{35} \mathrm{~S}$ as described by Riondel et al. for testosterone (11) with the modification of Lobotsky, Wyss, Segre, and Lloyd (12) and as described by Horton for androstenedione (13) with the modification of Mizuno et al. (14) $10-20 \mathrm{ml}$ of plasma was assayed. The blank of the method (1 ng/sample for testosterone and androstenedione) was subtracted from the values obtained.

The metabolic clearance rates of testosterone $\left(\mathrm{MCR}^{\mathrm{T}}\right)$ and of androstenedione $\left(\mathrm{MCR}^{\mathbf{\Lambda}}\right)$ were measured by the technique of Horton and Tait (5), and their abbreviations

TABLE I

Clinical Data

\begin{tabular}{cccccc}
\hline $\begin{array}{c}\text { Subject } \\
\text { number }\end{array}$ & Age & Weight & Height & $\begin{array}{c}\text { Cycle } \\
\text { length }\end{array}$ & $\begin{array}{c}\text { Day of } \\
\text { thermal } \\
\text { nadir }\end{array}$ \\
\hline$y r$ & $l b$. & days
\end{tabular}

Group I : normal female subjects

$\begin{array}{llllll}1 & 21 & 130 & 5 \mathrm{ft} 6 \text { in. } & 24 & 11 \\ 2 & 21 & 125 & 5 \mathrm{ft} 8 \text { in. } & 28 & 15 \\ 3 & 23 & 100 & 5 \mathrm{ft} 6 \text { in. } & 26 & 14 \\ 4 & 23 & 118 & 5 \mathrm{ft} 5 \text { in. } & 27 & 15 \\ 5 & 28 & 113 & 5 \mathrm{ft} 5 \frac{1}{2} \text { in. } & 26 & - \\ 6 & 21 & 135 & 5 \mathrm{ft} 5 \mathrm{in} . & 33 & 19\end{array}$

\author{
Slight hirsutism; moderate acne (face and back) \\ Severe premenstrual tension \\ Moderate premenstrual tension; moderate acne (back) \\ Slight dysmenorrhea .
}

Group 51 : overiectomized subjects*

$\begin{array}{rlll}7 & 67 & 138 & 5 \mathrm{ft} 3 \mathrm{in} . \\ 8 & 49 & 150 & 5 \mathrm{ft} 5 \frac{1}{2} \mathrm{in} . \\ 9 & 58 & 174 & 5 \mathrm{ft} 6 \frac{1}{2} \mathrm{in} . \\ 10 & 40 & 165 & 6 \mathrm{ft} \\ \cdot 11 & 51 & 118 & 5 \mathrm{ft} 5 \mathrm{in} . \\ 12 & 45 & 160 & 5 \mathrm{ft} 2 \mathrm{in} .\end{array}$

$1945 \ddagger$; Uterine fibroids

1952; Cancer of cervix in situ

1965 ; Uterine fibroids

1962; Cervical cancer

1961 ; Cervical cancer

1961 ; Recurrent vaginal bleeding

* Each subject had a hysterectomy and bilateral salpingo-oophorectomy.

$\ddagger$ Year $=$ date of surgery. 
TABLE II

Infusion Rates and Plasma Concentration of Isotopic Steroids*

\begin{tabular}{|c|c|c|c|c|c|c|c|}
\hline \multirow{2}{*}{$\begin{array}{l}\text { Subject } \\
\text { number }\end{array}$} & \multirow{2}{*}{$\begin{array}{c}\text { Day ot } \\
\text { intusion } \ddagger\end{array}$} & T-8H & $\mathrm{A}-{ }^{14} \mathrm{C}$ & T- ${ }^{2} \mathrm{H}$ & $\mathrm{T}-14 \mathrm{C}$ & A-8 $\mathrm{H}$ & A. $-14 \mathrm{C}$ \\
\hline & & \multicolumn{2}{|c|}{ Infusion rate } & \multicolumn{4}{|c|}{ Plasma concentration } \\
\hline & & $\operatorname{cpm} / \min$ & $\times 10^{4}$ & & $c p m / 2$ & $0 \mathrm{ml}$ & \\
\hline \multirow[t]{2}{*}{1} & $\mathrm{TN}-7$ & 1.35 & 1.57 & 452 & 47 & - & 276 \\
\hline & $\mathrm{TN}+5$ & 1.45 & 1.88 & 386 & 42 & - & 274 \\
\hline \multirow[t]{2}{*}{2} & $\mathrm{TN}-7$ & 1.38 & 1.70 & 422 & 33 & - & 283 \\
\hline & $\mathrm{TN}+1$ & 1.47 & 1.55 & 438 & 20 & - & 173 \\
\hline \multirow[t]{2}{*}{3} & $\mathrm{TN}-7$ & 1.58 & 1.94 & 868 & 46 & 22 & 399 \\
\hline & $\begin{array}{l}\mathrm{TN}+8 \\
\mathrm{TN}-7\end{array}$ & $\begin{array}{l}2.28 \\
3.67\end{array}$ & $\begin{array}{l}2.09 \\
1.45\end{array}$ & $\begin{array}{l}1143 \\
1314\end{array}$ & $\begin{array}{l}36 \\
22\end{array}$ & $\begin{array}{l}26 \\
69\end{array}$ & $\begin{array}{l}349 \\
236\end{array}$ \\
\hline 4 & TN 0 & 3.65 & 1.62 & 1343 & 22 & 72 & 272 \\
\hline \multirow[t]{2}{*}{5} & $8 \|$ & 3.41 & 1.35 & 1157 & 17 & 43 & 186 \\
\hline & 15 & 3.49 & 1.33 & 1202 & 20 & 38 & 196 \\
\hline \multirow[t]{2}{*}{6} & $\mathrm{TN}-4$ & 3.84 & 1.61 & 1415 & 29 & 35 & 272 \\
\hline & $\mathrm{TN}+7$ & 3.81 & 1.76 & 1185 & 24 & 24 & 218 \\
\hline 7 & & 3.83 & 1.32 & 1775 & 22 & 38 & 198 \\
\hline 8 & & 4.45 & 2.48 & 2140 & 42 & 92 & 416 \\
\hline 9 & & 4.12 & 1.48 & 1627 & 29 & 41 & 202 \\
\hline 10 & & 3.42 & 1.95 & 1916 & 30 & 69 & 310 \\
\hline 11 & & 3.69 & 1.62 & 2203 & 33 & 62 & 265 \\
\hline 12 & & 3.84 & 1.42 & 2477 & 26 & 79 & 229 \\
\hline
\end{tabular}

${ }^{*} \mathrm{~T}-{ }^{3} \mathrm{H}$ and $\mathrm{T}-{ }^{14} \mathrm{C}=$ testosterone ${ }^{-3} \mathrm{H}$ and $-{ }^{14} \mathrm{C} ; \mathrm{A}-{ }^{3} \mathrm{H}$ and $\mathrm{A}-{ }^{14} \mathrm{C}=$ androstenedione ${ }^{-3} \mathrm{H}$ and ${ }^{14} \mathrm{C}$.

$\ddagger$ Day of infusion in relation to day of thermal nadir (TN).

$\S$ Mean of three values obtained at 90,105 , and $120 \mathrm{~min}$ of the infusion.

\| Anovulatory cycle.

are used. $100 \mu \mathrm{g}$ each of testosterone and androstenedione in $1 \mathrm{ml}$ of ethanol were added to a $50 \mathrm{ml}$ glass-stoppered centrifuge tube. The ethanol was evaporated under a stream of nitrogen at $40^{\circ} \mathrm{C}$ and the residue redissolved in $0.4 \mathrm{ml}$ of ethanol. With the same $1 \mathrm{ml}$ pipette, $100 \mu \mathrm{g}$ each of these two steroids were transferred into separate vials, dried, and stored at $4^{\circ} \mathrm{C}$ to serve as the standard steroids used for recovery. To the $50 \mathrm{ml}$ centrifuge tube containing the two steroids was added $20 \mathrm{ml}$ of plasma, and mixture was accomplished by shaking for $5 \mathrm{~min}$. The plasma samples were extracted as described by Levin, Lloyd, Lobotsky, and Friedrich (15) for testosterone. The chromatographic system used after extraction was as described by Horton and Tait (5). The eluates of the testosterone and androstenedione fractions obtained after paper chromatography were dried down in counting vials, together with their corresponding paper blanks for each of the steroids. The paper blanks were obtained by cutting an equal surface area next to each of the two steroids measured. To the counting vials, including the standards, was added $10 \mathrm{ml}$ of ethanol, and a Vortex mixer (Lawrence Pump \& Engine Co., Lawrence, Mass.) was used to dissolve the steroids and the paper blank residue. $3 \mathrm{ml}$ of the ethanolic solution was used for ultraviolet absorption measurements (UV) at $240 \mathrm{~m} \mu$ in a Beckman DU spectrophotometer. The standard steroids were read against pure ethanol and the unknowns against the paper blanks. The recovery of each steroid was estimated in this manner. The remaining $7 \mathrm{ml}$ of ethanolic solution in the counting vials was evaporated, counting fluid was added, and after mixing, the samples were assayed for ${ }^{3} \mathrm{H}$ and ${ }^{14} \mathrm{C}$ content with a $\mathrm{Nu}$ clear-Chicago liquid scintillation spectrometer model 720 . Discriminator and gain settings were such that the efficiency for ${ }^{8} \mathrm{H}$ was $15 \%$ and for ${ }^{14} \mathrm{C} 42 \%$. The efficiency for ${ }^{3} \mathrm{H}$ in the ${ }^{14} \mathrm{C}$ channel was less than $0.1 \%$, and the efficiency for ${ }^{14} \mathrm{C}$ in the ${ }^{3} \mathrm{H}$ channel was $5 \%$. For the errors involved in radioactivity measurements, see section on errors of the method. At no time were there any counts in the ${ }^{3} \mathrm{H}$ and ${ }^{14} \mathrm{C}$ channels above background when the paper blanks were counted. No quenching effect could be detected for either of the two isotopes. Samples were counted for $10 \times 20 \mathrm{~min}$. The metabolic clearance rate was calculated from the rate of infusion of the isotope divided by the concentration of isotope in the specific steroid per volume of plasma. Evidence that the infused steroids reached equilibrium during the $2 \mathrm{hr}$ period was provided by the fact that there was no trend in the three values, and the coefficient of variation for these three samples was less than $10 \%$ for the testosterone- ${ }^{3} \mathrm{H}$ and for the androstenedione $-{ }^{14} \mathrm{C}$, and less than $20 \%$ for androstenedione- ${ }^{8} \mathrm{H}$ and testosterone $-{ }^{14} \mathrm{C}$ except in subject Nos. 1 and 2 where the coefficient of variation of androstenedione- ${ }^{8} \mathrm{H}$ was over $20 \%$. Those latter values, for this reason, are not included in this study.

Evidence for radiochemical purity of the testosterone and androstenedione fractions obtained in this way was presented by Horton and Tait (5). Additional evidence was obtained for testosterone $-{ }^{8} \mathrm{H}$ and androstenedione $-{ }^{14} \mathrm{C}$. One subject, infused during the follicular phase of her cycle, was dropped from the study. Her plasma samples were processed as described above. The paper eluates were pooled for each of the two steroids (total plasma volume, $60 \mathrm{ml}$ ). $15 \mathrm{mg}$ each of testosterone and androstenedione was added to the corresponding paper eluate. This was mixed and an aliquot taken for estimation of specific activity. The remaining volume was dried down and the residue redissolved in ether. After three successive crystallizations in ether:hexane, the variations observed in the specific activity of testosterone $-{ }^{3} \mathrm{H}$ and androstenedione $-{ }^{14} \mathrm{C}$ were within the error of the method. (The specific activity in counts per minute per milligram for the eluate, the 1 st, 2 nd, and 3rd crystallizations were 92 , 95, 91 , and 91 for testosterone $-{ }^{8} \mathrm{H}$ and $24,22.4,23.6$, and 22.8 for androstenedione $-{ }^{14} \mathrm{C}$.)

Calculations. The symbols and calculations for the several parameters of the testosterone-androstenedione system are those of Horton and Tait (5). The superscripts indicate the steroid, the subscripts the compartment. The symbol $Z$ refers to the isotope in testosterone and $X$ to the isotope in androstenedione. The formulas used are as follows:

$$
\mathrm{MCR}^{\mathrm{T}}=\mathrm{R}_{\mathrm{Z}}^{\mathrm{T}} / \mathrm{Z}^{\mathrm{T}} \text { and } \mathrm{MCR}^{\mathrm{A}}=\mathrm{R}_{\mathrm{X}^{\mathrm{A}}} / \mathrm{N}^{\cdot 1}
$$

where $\mathrm{R}_{\mathrm{Z}}{ }^{\mathrm{T}}$ is the ${ }^{3} \mathrm{H}$ count rate infused per unit time, and $\mathrm{Z}^{\mathrm{T}}$ is the concentration of testosterone- ${ }^{3} \mathrm{H}$ in counts per minute (cpm) per unit volume of plasma. The expressions for androstenedione are analogous.

$$
\mathrm{P}_{\mathrm{B}}^{\mathrm{T}}=\mathrm{MCR}^{\mathrm{T}} \times \mathrm{i}^{\mathrm{T}} \text { and } \mathrm{P}_{\mathrm{B}^{\mathrm{A}}}=\mathrm{MCR}^{\mathrm{A}} \times \mathrm{i}^{\mathrm{A}}
$$

where $P_{B}{ }^{T}$ is the blood production rate, and $i^{T}$ is the blood testosterone concentration.

$$
\mathrm{C}_{\mathrm{BB}}{ }^{\mathrm{AT}}=\mathrm{X}^{\mathrm{T}} / \mathrm{X}^{\mathrm{A}} \text { and } \mathrm{C}_{\mathrm{BB}}{ }^{\mathrm{TA}}=Z^{\mathrm{A}} / Z^{\mathrm{T}}
$$

where $\mathrm{C}_{\mathrm{BB}} \mathrm{AT}^{\mathrm{T}}$ is the conversion ratio of androstenedione to. testosterone in blood.

and

$$
[\rho]_{\mathbf{B B}^{A T}}{ }^{\mathrm{T}}=\mathrm{C}_{\mathrm{BB}}{ }^{\mathrm{AT}} \times \mathrm{MCR}^{\mathrm{T}} / \mathrm{MCR}^{\mathrm{A}} \text {, }
$$

$$
[\rho]_{\mathrm{BB}^{\mathrm{TA}}}=\mathrm{C}_{\mathrm{BB}^{\mathrm{TA}}} \times \mathrm{MCR}^{\mathrm{A}} / \mathrm{MCR}^{\mathrm{T}}
$$


TABLE III

Concentrations, Production Rates, and Interconversion of Plasma Testosterone and Androstenedione*

\begin{tabular}{|c|c|c|c|c|c|c|c|c|c|c|}
\hline Subjects & $i \mathbf{T}$ & $i \mathrm{~A}$ & MCRT & MCRA & $\mathbf{P}_{\mathrm{B}} \mathbf{T}$ & $\mathbf{P}_{\mathbf{B}} \mathbf{A}$ & $\mathrm{C}_{\mathrm{BB} A \mathrm{~A}}$ & $\mathrm{C}_{\mathrm{BB}} \mathrm{TA}$ & {$[\rho]_{\mathrm{BB}} \mathrm{AT}$} & {$[\rho]_{\mathrm{BB}} \mathrm{TA}$} \\
\hline Group I & \multicolumn{2}{|c|}{$\mu g /$ liter } & \multicolumn{2}{|c|}{ lilers $/ 24 \mathrm{hr}$} & \multicolumn{2}{|c|}{$\mu g / 24 h r$} & & & & \\
\hline 1. $\mathrm{TN}-7$ & 1.010 & 1.67 & 858 & 1631 & 867 & 2724 & 0.150 & - & 0.079 & - \\
\hline $\mathrm{TN}+5$ & 0.865 & 1.23 & 1083 & 1971 & 937 & 3804 & 0.158 & - & 0.087 & - \\
\hline 2. $\mathrm{TN}-7$ & 0.373 & 1.63 & 942 & 1730 & 351 & 2924 & 0.117 & - & 0.064 & - \\
\hline $\mathrm{TN}+1$ & 0.408 & 1.81 & 968 & 2594 & 395 & 4695 & 0.113 & - & 0.042 & 一 \\
\hline 3. $\mathrm{TN}-7$ & 0.558 & 1.90 & 524 & 1402 & 292 & 2664 & 0.105 & 0.025 & 0.039 & 0.054 \\
\hline $\mathrm{TN}+8$ & 0.524 & 2.35 & 575 & 1718 & 301 & 4037 & 0.108 & 0.023 & 0.036 & 0.063 \\
\hline 4. $\mathrm{TN}-7$ & 0.510 & 2.08 & 804 & 1763 & 410 & 3667 & 0.094 & 0.052 & 0.043 & 0.114 \\
\hline TN 0 & 0.656 & 2.51 & 784 & 1716 & 514 & 4307 & 0.081 & 0.054 & 0.037 & 0.118 \\
\hline 5. Day 8 & 0.643 & 2.48 & 843 & 2100 & 546 & 5208 & 0.091 & 0.037 & 0.037 & 0.092 \\
\hline Day 15 & 0.928 & 2.31 & 838 & 1956 & 778 & 4518 & 0.103 & 0.031 & 0.044 & 0.072 \\
\hline 6. $\mathrm{TN}-4$ & 0.388 & 1.38 & 782 & 1715 & 303 & 2368 & 0.107 & 0.025 & 0.049 & 0.055 \\
\hline $\mathrm{TN}+7$ & 0.390 & 1.65 & 926 & 2332 & 361 & 3848 & 0.110 & 0.020 & 0.044 & 0.050 \\
\hline Mean & 0.604 & 1.98 & 828 & 1886 & 505 & 3730 & 0.111 & 0.033 & 0.05 & 0.078 \\
\hline$\pm \mathrm{SE}$ & \pm 0.064 & \pm 0.11 & \pm 45 & \pm 228 & \pm 67 & \pm 259 & \pm 0.006 & \pm 0.005 & \pm 0.005 & \pm 0.010 \\
\hline \multicolumn{11}{|l|}{ Group II } \\
\hline 7. & 0.482 & 0.673 & 621 & 1919 & 299 & 1291 & 0.113 & 0.021 & 0.037 & 0.065 \\
\hline 8. & 0.443 & 0.814 & 626 & 1716 & 277 & 1397 & 0.101 & 0.043 & 0.037 & 0.118 \\
\hline 9. & 0.468 & 0.661 & 548 & 2107 & 256 & 1393 & 0.143 & 0.025 & 0.037 & 0.096 \\
\hline 10. & 0.321 & 1.08 & 514 & 1814 & 165 & 1959 & 0.096 & 0.036 & 0.027 & 0.127 \\
\hline 11. & 0.545 & 1.14 & 482 & 1762 & 263 & 2003 & 0.124 & 0.028 & 0.034 & 0.102 \\
\hline 12. & 0.688 & 0.937 & 446 & 1782 & 307 & 1670 & 0.115 & 0.032 & 0.029 & 0.128 \\
\hline Mean & 0.491 & 0.884 & 540 & 1850 & 261 & 1620 & 0.115 & 0.031 & 0.034 & 0.106 \\
\hline$\pm \mathrm{SE}$ & \pm 0.049 & \pm 0.082 & \pm 30 & \pm 152 & \pm 21 & \pm 126 & \pm 0.006 & \pm 0.003 & \pm 0.002 & \pm 0.010 \\
\hline
\end{tabular}

* See text for explanation of symbols.

where $[\rho]_{\mathbf{B B}^{\mathrm{AT}}}{ }^{\mathrm{T}}$ is the total fraction of secreted androstenedione converted to testosterone as measured in peripheral blood.

\section{RESULTS}

Plasma steroids. When the plasma concentration of testosterone and androstenedione $\left(\mathrm{i}^{\mathbf{T}}\right.$ and $\left.\mathrm{i}^{\mathbf{A}}\right)$ obtained from the subjects in group I were pooled and compared with those obtained in the group II subjects (Table III) no significant difference was found for $\mathrm{i}^{\mathrm{T}}(0.604 \pm 0.064$ (SE) $\mu \mathrm{g} /$ liter for group I vs. $0.491 \pm 0.049$ (SE) $\mu \mathrm{g} /$ liter for group II), whereas $\mathrm{i}^{\mathbf{A}}$ was higher in the subjects of group I (1.98 \pm 0.11 (SE) $\mu \mathrm{g}$ /liter vs. $0.884 \pm$ 0.082 ( $\mathrm{SE}) \mu \mathrm{g} /$ liter). This difference was highly significant $(P<0.01)$. Also, there was no overlap in the individual values of the two groups. It is interesting to note that subject Nos. 1 and 5 who had the highest $i^{\mathbf{T}}$ also had some clinical evidence of androgenicity (Table I).

Comparison of the values obtained during the follicular and luteal phases of the menstrual cycle revealed no significant change in $\mathbf{i}^{\mathbf{T}}$ (Fig. 1), but $\mathrm{i}^{\mathbf{\Lambda}}$ was significantly higher in the luteal phase. The values in micrograms per liter in the follicular and luteal phases were respectively: for testosterone, $0.582 \pm 0.148$, SE and $0.547 \pm 0.110$, sE; for androstenedione, $1.66 \pm 0.107$, SE and $1.94 \pm 0.150$, SE $(P<0.05)$.

Metabolic clearance rates. The mean $\mathrm{MCR}^{\mathrm{T}}$ of normal women (group I) was significantly higher $(P<$ 0.05 ) than the mean of the ovariectomized subjects (group II). There was no significant difference among the two groups for $\mathrm{MCR}^{\mathbf{A}}$. These data are summarized in Table III. Comparison of the two phases of the menstrual cycle (Fig. 2) showed a small and statistically not significant difference in $\mathrm{MCR}^{\mathbf{T}}$ (780 \pm 90 (SE) liters/ $24 \mathrm{hr}$ vs. $890 \pm 105$ ( $\mathrm{SE}$ ) liters $/ 24 \mathrm{hr}$ ), whereas $\mathrm{MCR}^{\mathrm{A}}$ increased significantly $(P<0.05)$ in the luteal phase (1620 \pm 75 (SE) liters $/ 24$ hr vs. $2150 \pm 190$ (SE) liters/ $24 \mathrm{hr}$ ).

Blood production rates. Blood production rates of testosterone and androstenedione $\left(\mathrm{P}_{\mathrm{B}}{ }^{\mathrm{T}}\right.$ and $\left.\mathrm{P}_{\mathrm{B}}{ }^{\mathbf{A}}\right)$ were 


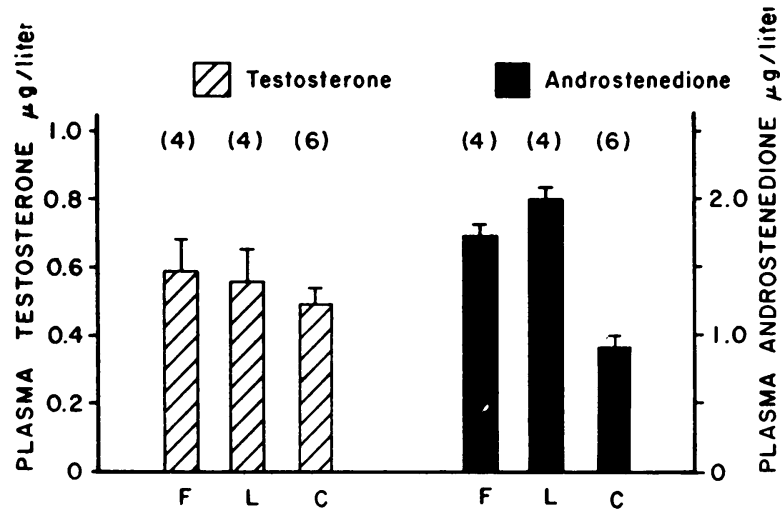

Figure 1 Plasma testosterone and androstenedione concentrations during the follicular $(F)$ and luteal $(L)$ phases of the menstrual cycle and in ovariectomized women $(C)$. Mean values (bar heights) \pm standard error.

higher $(P<0.01)$ in the normal than in the ovariectomized subjects (see Table III). $\mathrm{P}_{\mathbf{B}}{ }^{\mathrm{T}}$ showed no significant change during the two phases of the menstrual cycle, whereas $P_{B}{ }^{A}$ increased significantly $(P<0.01)$ in the luteal phase (Fig. 3 ).

Conversion ratios and $[\rho]$ values. The conversion ratio of androstenedione to testosterone in blood $\left(\mathrm{C}_{\mathrm{BB}}{ }^{{ }^{\mathrm{T}}}\right)$ and vice versa $\left(\mathrm{C}_{\mathbf{B B}}{ }^{\mathrm{TA}}\right)$ were the same in group I subjects as those obtained in group II subjects. Also, these conversion ratios showed no difference between the follicular and luteal phases. These values are summarized in Table III. The total fraction of secreted androstenedione converted to testosterone as measured in peripheral blood $\left([\rho]_{\mathbf{B}} \mathbf{B}^{\mathbf{T}}\right)$ and vice versa $\left([\rho]_{\mathbf{B B}}{ }^{\mathrm{TA}}\right)$ were not significantly different in the follicular than in the luteal phases. When subjects of group I were compared with those of group II, $[\rho]_{\mathrm{BB}}{ }^{\mathrm{TA}}$ was higher in group II $(0.106$ $\pm 0.010 \mathrm{SE}$ compared with $0.078 \pm 0.010 \mathrm{SE}$ for group I),
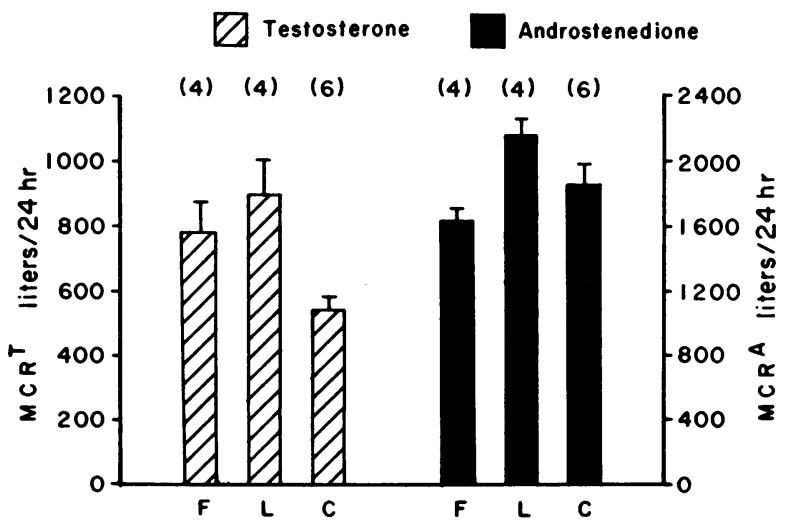

Figure 2 Metabolic clearance rate of testosterone and androstenedione during the follicular $(F)$ and luteal $(L)$ phases of the menstrual cycle and in ovariectomized women $(C)$. Mean values (bar heights) \pm standard errors.

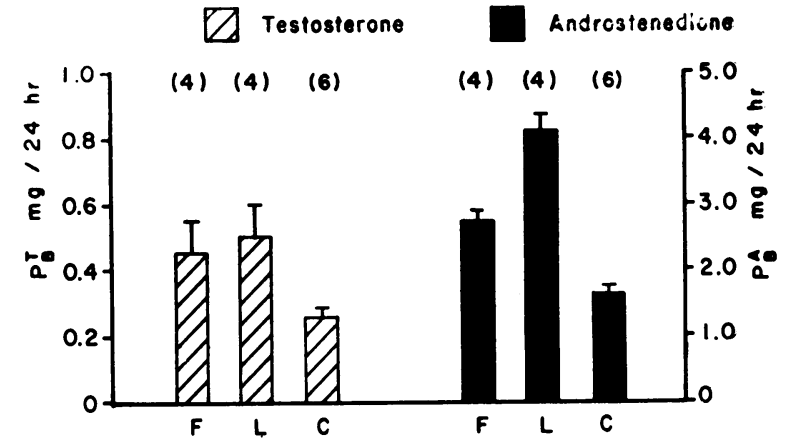

Figure 3 Blood production rate of testosterone and androstenedione during the follicular $(F)$ and luteal $(L)$ phases of the menstrual cycle and in ovariectomized women $(C)$. Mean values (bar heights) \pm standard error.

but this difference was not significant at the 0.05 level. However, $[\rho]_{\mathrm{BB}^{\mathrm{B}}}{ }^{\mathrm{T}}$ was significantly lower $(P<0.05)$ in subjects of group II $(0.034 \pm 0.002$ SE vs. $0.050 \pm 0.005$ $\mathrm{SE}$ in group I). The difference found among the two groups studied in $[\rho]_{\mathrm{BB}^{\mathrm{AT}}}$ could be attributed to the difference found in $\mathrm{MCR}^{\mathrm{T}}$, since $\mathrm{C}_{\mathbf{B B}}{ }^{\mathbf{A T}}$ and $\mathrm{MCR}^{\boldsymbol{A}}$ were the same in the two groups.

With the above data, and assuming that the endogenously produced steroids are completely mixed with the radioisotopically labeled steroids infused and that they follow the same metabolic pathway, it is estimated that $33 \%$ of $\mathrm{i}^{\mathrm{T}}$ in the normal subjects is derived from $\mathrm{i}^{\mathrm{A}}$. Also, $37 \%$ of $\mathrm{P}_{\mathrm{B}}^{\mathrm{T}}$ is derived from $\mathrm{P}_{\mathrm{B}^{\mathrm{A}}}$. On the other hand, the contribution of $i^{\mathrm{T}}$ and $\mathrm{P}_{\mathrm{B}}{ }^{\mathrm{T}}$ to $\mathrm{i}^{\mathrm{A}}$ and $\mathrm{P}_{\mathrm{B}}{ }^{\mathrm{A}}$ was insignificant (less than $1 \%$ ).

In the ovariectomized subjects $20 \%$ of $i^{T}$ and of $P_{B}{ }^{T}$ is derived respectively from $i^{\mathbf{A}}$ and $\mathrm{P}_{\mathbf{B}}{ }^{\mathbf{A}}$.

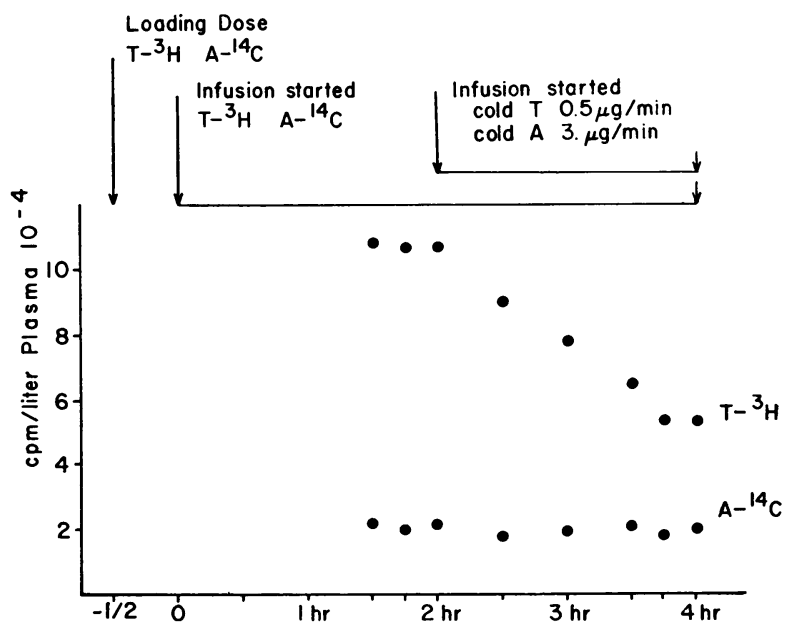

Figure 4 Effect of the infusion of testosterone (cold $\mathrm{T}$ ) and androstenedione (cold A) at physiologic level on the plasma isotopic levels of testosterone $-{ }^{3} \mathrm{H}\left(\mathrm{T}-{ }^{3} \mathrm{H}\right)$ and androstenedione $-{ }^{14} \mathrm{C}\left(\mathrm{A}-{ }^{14} \mathrm{C}\right)$. 
TABLE IV

Effect of Estrogen Treatment on $M C R^{T}$ and $M C R^{A}$ before and during Infusion of Nonlabeled Testosterone and Androstenedione in an Ovariectomized Subject

\begin{tabular}{|c|c|c|}
\hline & $\begin{array}{c}\text { Before } \\
\text { infusion }\end{array}$ & $\begin{array}{c}\text { After } \\
\text { infusion }\end{array}$ \\
\hline \multicolumn{3}{|c|}{ Before estrogen treatment } \\
\hline $\mathrm{MCR}^{\mathrm{T} *}$ & 626 & 1175 \\
\hline $\mathrm{MCR}^{\mathrm{A}}$ & 1716 & 1720 \\
\hline \multicolumn{3}{|c|}{ After estrogen treatment $\ddagger$} \\
\hline $\mathrm{MCR}^{\mathrm{T}}$ & 540 & 585 \\
\hline $\mathrm{MCR}^{\mathrm{A}}$ & 1636 & 1712 \\
\hline
\end{tabular}

* Expressed in liters/day.

$\ddagger$ Premarin $(1.25 \mathrm{mg} /$ day $\times 6 \mathrm{wk})$.

Effect of the acute administration of testosterone and androstenedione at physiological level on $M C R^{r}$ and $M C R^{\mathbf{A}}$. To study the effect of $\mathrm{P}_{\mathrm{B}}{ }^{\mathrm{T}}$ and $\mathrm{P}_{\mathrm{B}}{ }^{\mathrm{A}}$ upon $\mathrm{MCR}^{\mathrm{T}}$ and MCR ${ }^{\Delta}$, subject No. 8 was infused with testosterone and androstenedione after blood samples were drawn for determination of $\mathrm{MCR}^{\mathbf{T}}$ and $\mathrm{MCR}^{\mathbf{\Delta}}$. The details of this experiment are described in the Methods section. The results of this infusion are shown in Fig. 4. The rate of testosterone and androstenedione infused corresponds to a $\mathrm{P}_{\mathbf{B}}{ }^{\mathrm{T}}$ of $720 \mu \mathrm{g} /$ day and to a $\mathrm{P}_{\mathbf{B}}{ }^{\mathbf{A}}$ of 4320 $\mu \mathrm{g} /$ day, which are within physiologic levels for the normal female subjects studied (group I). Yet, the $M C^{T}$ almost doubled under these conditions, whereas $\mathrm{MCR}^{\mathbf{\Lambda}}$ remained essentially the same. This subject (No. 8) was then placed on oral estrogen therapy for $6 \mathrm{wk}$ (Premarin, ${ }^{1} 1.25 \mathrm{mg} / \mathrm{day}$ ) and the same experiment as described above was repeated. The results are summarized in Table IV. The $\mathrm{MCR}^{\mathbf{T}}$ under basal conditions was slightly lower than before estrogen treatment (540 liters/ $24 \mathrm{hr}$ compared with 626 liters $/ 24 \mathrm{hr}$ ). The infusion of testosterone at a rate of $0.5 \mu \mathrm{g} / \mathrm{min}$ did not significantly influence $\mathrm{MCR}^{\mathrm{T}}$ after estrogen therapy. When comparing either before and after estrogen administration, or before and after androstenedione infusion, no change was noted whatsoever for MCR ${ }^{\mathbf{A}}$.

\section{DISCUSSION}

Testosterone. In the subjects studied, no change was observed in $\mathrm{i}^{\mathbf{T}}$ when the two phases of the menstrual cycle were compared. In a previous study with a larger number of subjects (12), the highest $\mathrm{i}^{\mathbf{T}}$ during the menstrual cycle were found at about the time of thermal nadir. Since the present study did not cover every day of the menstrual cycle due to obvious practical difficulties, short-lived acute changes in any of the parameters studied might not have been detected.

\footnotetext{
${ }^{1}$ Estrogens conjugates (Equine) from Ayerst Laboratories, New York.
}

Study of $\mathrm{MCR}^{\mathrm{T}}$ and $\mathrm{P}_{\mathrm{B}}^{\mathrm{T}}$ in the follicular and luteal phase of the normal menstrual cycle has not been previously reported. In the four subjects investigated no significant difference was found between the two phases of the menstrual cycle.

The mean $\mathrm{P}_{\mathrm{B}} \mathrm{T}$ in the ovariectomized subjects was about half that in the normal women, but since the $\mathrm{MCR}^{\mathrm{T}}$ was also significantly lower in the ovariectomized women, this resulted in a mean $i^{\mathbf{T}}$ not significantly different among these two groups. This finding does not necessarily mean that half of $P_{B}{ }^{T}$ is contributed by the ovaries, since the two groups of subjects were in different age groups, and this factor might have contributed to this difference. In this regard, Kent and Acone reported (16) a lower $M C R^{T}$ and $P_{B}{ }^{T}$ in older men. The measurement of $M C R^{T}$ and $P_{B}{ }^{T}$ in the same women before and after ovariectomy would help clarify this matter.

Correction for body weight and body surface did not affect this difference in $\mathrm{MCR}^{\mathrm{T}}$ between the normal and ovariectomized subjects.

Androstenedione. $\mathrm{i}^{\mathbf{\Lambda}}, \mathrm{MCR}^{\mathbf{\Lambda}}$, and $\mathrm{P}_{\mathrm{B}}{ }^{\mathbf{A}}$ increased significantly in the luteal phase. This increase in $P_{\mathbf{B}}{ }^{A}$ could be due to the contribution of the corpus luteum and the ovarian stroma as suggested by in vitro studies (17).

$\mathrm{i}^{\mathbf{\Lambda}}$ and $\mathrm{P}_{\mathbf{B}}{ }^{\boldsymbol{A}}$ in ovariectomized subjects were less than half those in normal subjects. Assuming that this difference is not due to age difference between the two groups of subjects, the conclusion can be drawn that the ovaries contributed to at least $50 \%$ of $\mathrm{P}_{\mathrm{B}}{ }^{\mathrm{T}}$ and $\mathrm{P}_{\mathrm{B}}{ }^{\mathrm{A}}$.

Horton, Romanoff, and Walker (18) found in five female patients undergoing surgery for metastatic breast cancer that the ovarian secretion of testosterone was quite small, and that the ovaries contributed less than one-fourth of $P_{\mathbf{B}}{ }^{\mathbf{A}}$. Since these subjects were not normal, and since there is little information about androgen metabolism in patients with breast cancer, extrapolation of these findings to normal female subjects would be hazardous.

Horton and Tait (5) and Bardin and Lipsett (19) reported values higher than those reported in this study concerning the percentage of $i^{\mathrm{r}}$ derived from $\mathrm{i}^{\mathbf{A}}$. This difference could be due to the lower $\mathrm{i}^{\mathbf{T}}$ levels found in a number of the female subjects studied by those two groups of investigators. Nevertheless, there is agreement on the important role of androstenedione as a prehormone (20). Most of the $\mathrm{C}_{\mathrm{BB}}{ }^{\mathrm{AT}}$ occurs outside of the liver $(5,21)$. It is possible that this conversion occurs in target tissues where testosterone has a physiologic role. This role in the normal woman is not yet known. The uterus and the ovaries do not seem important in $\mathrm{C}_{\mathbf{B B}}{ }^{\mathrm{AT}}$, since these values were not different in normal and ovariectomized-hysterectomized subjects.

Effect of $P_{B}{ }^{r}$ on $M C R^{r}$. Southern et al. (22) reported that injection of testosterone enanthate at a dose 
of $200 \mathrm{mg}$ weekly increased significantly the $\mathrm{MCR}^{\mathrm{T}}$ in some female patients studied. Since the dosage of testosterone used in this study far exceeded physiologic levels in normal women, any physiological significance of these findings is only tentative. More recently, Southern, Gordon, and Tochimoto (23) were able to produce acute changes of $\mathrm{MCR}^{\mathrm{T}}$ in normal women by infusing pharmacologic levels of testosterone, whereas infusion of physiologic doses of testosterone did not cause any detectable rise in $\mathrm{MCR}^{\mathbf{T}}$. Bardin and Lipsett (19) found a significantly positive correlation between $\mathrm{MCR}^{\mathrm{T}}$ and $\mathbf{P}_{B}{ }^{\mathbf{T}}$ in normal and hirsute females. They interpreted this correlation as being consistent with a depression of a testosterone-binding protein by increased testosterone production.

We have been able to demonstrate an acute change in $\mathrm{MCR}^{\mathrm{T}}$ after infusion of a physiological dose of testosterone in an ovariectomized subject. In view of the results reported by others (23), and since we only have one such experiment, a valid explanation for this finding must await more extensive studies. Nevertheless, acute and chronic changes produced by testosterone could either be due to an increase in hepatic blood flow or to induction of enzymes involved in the metabolism of testosterone. Another explanation, however, could come from the studies of Pearlman and Crepy (24) who showed a significant binding of testosterone by human plasma, and that this binding capacity of plasma was dependent upon estrogen (25). Testosterone bound to plasma albumin can be considered as physiologically free testosterone since this binding is of low affinity (26). On the other hand, testosterone is bound to a specific $\beta$-globulin of limited capacity and high affinity, and its capacity is increased by estrogen treatment (26). This latter protein could play an important role in the metabolism of testosterone, preventing rapid degradation by the liver and allowing certain target tissues possessing proteins with a high affinity for testosterone to selectively extract it from the blood. Studies involving concomitant evaluation of plasma binding capacity for testosterone together with the estimation of $\mathrm{MCR}^{\mathbf{x}}$ would shed some light on the physiological importance of this testosterone-binding protein.

\section{APPENDIX}

Errors of the method. The errors in the determination of $R_{Z}{ }^{T}$ and $R_{X^{A}}$ were always less than $5 \% . Z^{T}$ and $X^{A}$ were obtained after correction for recovery was made with the optical density at $240 \mathrm{~m} \mu\left(O D_{240}\right)$. Since the paper blank for testosterone $\left(O D_{240}\right)$ varied from 0.008 to 0.020 , with a range of 0.012 , and the lowest reading of unknown samples was 0.270 (lowest recovery for testosterone, $45 \%$ ), the maximum error in $U V$ reading for testosterone was: $0.008 / 0.270 \times 100=3 \%$. The paper blank for androstenedione varied from 0.012 to 0.022 , with a range of 0.010 . Since the lowest $\mathrm{OD}_{240}$ read for unknown samples was 0.325 (lowest recovery for androstene- dione, $52 \%$ ) the maximum UV reading error for androstenedione would be: $0.010 / 0.325 \times 100=3 \%$. Therefore, by use of the formula $E_{T}=\sqrt{E_{1}^{2}+E_{2}^{2}+E_{3}^{2}}$, where $E_{T}=$ compounded error and $E_{1}, E_{2}, E_{3}$ represents respectively errors in delivery rate of radioactive steroids $\left(R_{\mathbf{Z}}{ }^{T}\right.$ and $\left.R_{X}{ }^{A}\right)$, in counting and in UV reading, then, the compounded error $E_{\mathrm{T}}=\sqrt{25+4+9}=\sqrt{38}=6.2 \%$. This compounded error applied both for $Z^{\mathrm{T}}$ and $\mathrm{X}^{\mathrm{A}}$, for they both had the same maximum error in calculating delivery rate $(5 \%)$, the same counting error $(2 \%)$, and the same UV reading error $(3 \%)$. Since only $70 \%$ of the recovered radioactive steroids was used for counting ( 7 out of $10 \mathrm{ml}$ of ethanolic solution), the per cent of recovery was multiplied by the factor 0.7 to obtain the true recovery of the labeled steroids in the counting vials.

For $Z^{T}, X^{A}$, and $X^{T}$, eoungh counts were accumulated to have a counting error of $2 \%$ or less. For $Z^{A}$, however, the counting error was much greater. Using Horton and Tait's approach (27) in dealing with low ${ }^{3} \mathrm{H}$ counts in the presence of high ${ }^{14} \mathrm{C}$ counts, the counting error of $Z^{\mathrm{A}}$ was obtained by applying the formula: $\%$ error $=(100 / \mathrm{H}) \sqrt{\frac{2 \mathrm{~b}+\mathrm{mc}}{\mathrm{T}}}$, where $\mathrm{H}={ }^{8} \mathrm{H}$ count rates in the ${ }^{3} \mathrm{H}$ channel $; \mathrm{b}=$ background count rates in the ${ }^{3} \mathrm{H}$ channel; $\mathrm{m}=$ ratio of ${ }^{14} \mathrm{C}$ count rates in the ${ }^{3} \mathrm{H}$ channel over ${ }^{14} \mathrm{C}$ count rates in the ${ }^{14} \mathrm{C}$ channel; $\mathrm{C}={ }^{14} \mathrm{C}$ count rates in the ${ }^{14} \mathrm{C}$ channel; $\mathrm{T}=$ total counting time. With the gain settings used, $b=28, \mathrm{~m}=0.12$. A total of $200 \mathrm{~min}$ of counting time $T$ were accumulated. The lowest count rate recorded for $\mathrm{H}$ was $9 \mathrm{cpm}$ with a $\mathrm{C}$ value of $140 \mathrm{cpm}$; therefore, the maximum counting errors in the determination of $Z^{A}$ would be: $\%$ error $=(100 / 9) \sqrt{\frac{56+0.12 \times 140}{200}}=100 / 9$ $\times 0.72=8 \%$.

For the determination of $\mathrm{X}^{\mathrm{T}}$ and $\mathrm{Z}^{\mathrm{A}}$, the compounded errors due to $E_{1}, E_{2}$, and $E_{3}$ were, respectively: for $X^{T}$,

$$
\mathrm{E}_{\mathrm{T}}=\sqrt{4+9+25}=\sqrt{38}=6.2 \%
$$

for $Z^{A}$,

$$
\mathrm{E}_{\mathrm{T}}=\sqrt{64+9+25}=\sqrt{98}=10 \% .
$$

With the above information, the errors of the calculated values in rounded numbers were as follows:

$$
\begin{gathered}
\mathrm{MCR}^{\mathrm{T}} \text { and } \mathrm{MCR}^{\mathrm{A}} \pm 8 \% \\
\mathrm{C}_{\mathrm{BB}}{ }^{\mathrm{AT}} \pm 9 \%, \mathrm{C}_{\mathrm{BB}^{\mathrm{TA}} \pm 12 \%,[\rho]_{\mathrm{BB}^{\mathrm{AT}}} \pm 15 \%} \\
{[\rho]_{\mathrm{BB}^{\mathrm{TA}}} \pm 17 \% .}
\end{gathered}
$$

The errors involved in the determination of $P_{B}{ }^{T}$ and $P_{B}{ }^{A}$ are derived from the errors in calculating $M C R^{T}$ and $M C R^{A}$ on the one hand, and $\mathrm{i}^{\mathrm{T}}$ and $\mathrm{i}^{\mathrm{A}}$ on the other. The errors involved in the determination of $\mathrm{i}^{\mathrm{T}}$ and $\mathrm{i}^{\mathrm{A}}$ in the range studied are less than $10 \%$. Therefore, the compounded errors for calculating $\mathrm{P}_{\mathrm{B}}^{\mathrm{T}}$ and $\mathrm{P}_{\mathrm{B}}{ }^{\mathrm{A}}$ should be less than $15 \%$.

Statistical analysis. Student's $t$ test (28) was used to compare data obtained from the normal female subjects (group I) with those obtained from the ovariectomized women (group II). When comparing the data obtained in the follicular phase with those obtained in the luteal phase in the same subjects, paired data analysis (28) was used.

\section{ACKNOWLEDGMENTS}

The authors wish to thank Dr. J. F. Tait for helpful criticism, Dr. E. L. Klaiber and Mrs. L. B. Cushman for assistance during the infusion experiments, and Mrs. D. $H$. Mongeon for typing the manuscript. 


\section{REFERENCES}

1. Vande Wiele, R. L., P. C. MacDonald, E. Gurpide, and S. Lieberman. 1963. Studies on the secretion and interconversion of the androgens. Recent Progr. Hormone Res. 19: 275.

2. Tait, J. F., and S. Burstein. 1964. In vivo studies of steroid dynamics in man. In The Hormones. Academic Press Inc., New York. 5: 441.

3. Beaulieu, E., C. Corpechot, F. Dray, R. Emiliozzi, M. Lebeau, P. Jarvis, and P. Robel. 1965. An adrenal-secreted "androgen": Dehydroisoandrosterone sulfate. Its metabolism and a tentative generalization on the metabolism of other steroid conjugates in man. Recent Progr. Hormone Res. 21: 411.

4. Southam, A. L., and F. P. Gonzaga. 1965. Systemic changes during the menstrual cycle. Amer. J. Gynecol. $91: 142$.

5. Horton, R., and J. F. Tait. 1966. Androstenedione production and interconversion rates measured in peripheral blood and studies on the possible site of its conversion to testosterone. J. Clin. Invest. 45: 301.

6. Gurpide, E., P. C. McDonald, A. Chapedelaine, R. L. Vande Wiele, and S. Lieberman. 1965. Studies on the secretion and interconversion of the androgens. II. Methods for estimation of rates of secretion and of metabolism from specific activities of urinary metabolites. J. Clin. Endocrinol. Metab. 25: 1537.

7. Camacho, A. M., and C. J. Migeon. 1964. Studies on the origin of testosterone in the urine of normal adult subjects and patients with various endocrine disorders. $J$. Clin. Invest. 43: 1083.

8. Korenman, S. G., and M. B. Lipsett. 1964. Is testosterone glucuronoside uniquely derived from plasma testosterone? J. Clin. Invest. 43: 2125.

9. Tait, J. F. 1963. Review: the use of isotopic steroids for the measurement of production rates in vivo. J. Clin. Endocrinol. Metab. 23: 1285.

10. Levin, J., E. H. Friedrich, and J. Lobotsky. 1965. Steroid adsorption on polyethylene tubing. J. Clin. Endocrinol. Metab. 25 : 1519.

11. Riondel, A., J. F. Tait, M. Gut, S. A. S. Tait, E. Joachim, and B. Little. 1963. Estimation of testosterone in human peripheral blood using S35-thiosemicarbazide. J. Clin. Endocrinol. Metab. 23: 620.

12. Lobotsky, J., I. Wyss, E. Segre, and C. W. Lloyd. 1964. Plasma testosterone in normal woman. J. Clin. Endocrinol. Metab. 24 : 1261.

13. Horton, R. 1965. Estimation of androstenedione in human peripheral blood with $35 \mathrm{~S}$-thiosemicarbazide. J. Clin. Endocrinol. Metab. 25: 1237.

14. Mizuno, M., J. Lobotsky, C. W. Lloyd, T. Kobayashi, and Y. Murasawa. 1968. Plasma androstenedione and testosterone during pregnancy and in the newborn. $J$. Clin. Endocrinol. Metab. 28: 1133.

15. Levin, J., C. W. Lloyd, J. Lobotsky, and H. Friedrich. 1967. The effect of epinephrine on testosterone production. Acta Endocrinol. 55: 184.

16. Kent, J. R., and A. B. Acone. 1966. Plasma testosterone levels and aging in males. In Androgens in Normal and Pathological Conditions. A Vermeulen and V. D. Exley, editors. Excerpta Medica Foundation, Amsterdam. 31.

17. Savard, K., J. M. Marsh, and B. F. Rice. 1965. Gonadotropins and ovarian steroidogenesis. Recent Progr. Hormone Res. 21: 285.

18. Horton, R., E. Romanoff, and J. Walker. 1966. Androstenedione and testosterone in ovarian venous and peripheral plasma during ovariectomy for breast cancer. J. Clin. Endocrinol. Metab. 26: 1267.

19. Bardin, C. W., and M. B. Lipsett. 1967. Testosterone and androstenedione blood production rates in normal women and women with idiopathic hirsutism or polycystic ovaries. J. Clin. Invest. 46: 891.

20. Baird, D., R. Horton, C. Longcope, and J. F. Tait. 1968. Steroid prehormones. Perspect. Biol. Med. 11: 384.

21. Rivarola, M. A., R. T. Singleton, and C. J. Migeon. 1967. Splanchnic extraction and interconversion of testosterone and androstenedione in man. J. Clin. Invest. 46: 2095.

22. Southren, A. L., G. G. Gordon, S. Tochimoto, G. Pinzon, D. R. Lane, and W. Stypulkowski. 1967. Mean plasma concentration, metabolic clearance and basal plasma production rates of testosterone in normal young men and women using a constant infusion procedure: effect of time of day and plasma concentration on the metabolic clearance rate of testosterone. J. Clin. Endocrinol. Metab. $27: 686$.

23. Southern, A. L., G. G. Gordon, and S. Tochimoto. 1968. Further study of factors affecting the metabolic clearance rate of testosterone in man. J. Clin. Endocrinol. Metab. 28: 1105.

24. Pearlman, W. H., and O. Crepy. 1967. Steroid-protein interaction with particular reference to testosterone binding by human serum. J. Biol. Chem. 242: 182.

25. Pearlman, W. H., O. Crepy, and M. Murphy. 1967. Testosterone-binding levels in the serum of women during the normal menstrual cycle, pregnancy, and the postpartum period. J. Clin. Endocrinol. Metab. 27 : 1012.

26. Vermeulen, A., and L. Verdonck. 1968. Studies on the binding of testosterone to human plasma. Steroids. 11: 609.

27. Horton, R., and J. F. Tait. 1967. In vivo conversion of dehydroisoandrosterone to plasma androstenedione and testosterone in man. J. Clin. Endocrinol. Metab. 27: 79.

28. Goldstein, A. 1965. Biostatistics. The Macmillan Company, New York. 1st edition. 34. 